\title{
Blood donor deferral: time for change? An evidence-based analysis
}

This article was published in the following Dove Press journal:

International Journal of Clinical Transfusion Medicine

24 May 2016

Number of times this article has been viewed

\author{
Vere Borra' \\ Giovani Vandewalle' \\ Hans Van Remoortel' \\ Veerle Compernolle ${ }^{1,2}$ \\ Emmy De Buck' \\ Philippe Vandekerckhove ${ }^{1-3}$ \\ 'Belgian Red Cross-Flanders, \\ Mechelen, ${ }^{2}$ Faculty of Medicine, \\ University of Ghent, Ghent, \\ ${ }^{3}$ Department of Public Health and \\ Primary Care, Faculty of Medicine, KU \\ Leuven, Leuven, Belgium
}

\begin{abstract}
Donor selection remains an important part in the safety of the blood supply all over the world. Yet, donor deferral criteria seem to be strongly based on the precautionary principle protecting safety and quality, and on supply and expense considerations. This review therefore provides an overview of the available evidence on donor exclusion criteria, as well as on their cost-effectiveness, for the most frequent reasons of donor deferral in our region. PubMed was queried to retrieve primary research studies, systematic reviews, and health technology assessments (HTAs) concerning donor exclusion criteria. With a similar approach, HTAs about the different blood-banking safety interventions were included. Reasons for donor deferral were recorded via the blood bank information system of the Belgian Red Cross-Flanders. Seven systematic reviews were identified: four on donor safety (hypotension, hypertension/type 2 diabetes, epilepsy, and higher age) and three on recipient safety (hemochromatosis, men who have sex with men, and endoscopy). Forty-three lowquality observational studies were included, as well as 16 HTAs: three about donor exclusion criteria and 13 cost-utility analyses about blood-banking safety interventions. In general, the available evidence for deferral reasons was of low quality, and for $60 \%$ of the top 30 reasons for excluding donors, no evidence was found. Blood banking shows its unique position as many safety measures far exceed the normally accepted cost of $€ 50,000 /$ quality-adjusted life-years. The historical model based on the precautionary principle and on supply and expense considerations provides adequate supplies of safe blood at a reasonable price. More and better primary research and evidence-based analyses are required, however, before this model can be replaced by an evidence-based approach. Meanwhile, policy makers should provide guidance at the level of principles, not at the level of technical measures, about the balance between patient and donor rights, and about the acceptable cost-effectiveness implications of these choices.
\end{abstract}

Keywords: blood donation, deferral criteria, evidence-based, health technology assessment

\section{Introduction}

Patients in need of blood products are entitled to an adequate supply of safe blood at an acceptable price. ${ }^{1}$ It is the balanced combination of supply, safety/quality, and cost considerations that explains how donor deferral historically developed in the bloodbanking sector. Blood donor deferral measures form an essential part of this paradigm since they are effective, cheap, and can be implemented rapidly in case of emerging threats (eg, HIV in the 1980s, West Nile Virus, amongst others). Blood donors can be deferred for reasons of donor or patient safety, product quality, or feasibility of the collection (Table 1). ${ }^{2}$
Correspondence: Philippe

Vandekerckhove

Belgian Red Cross-Flanders, Motstraat 40, B-2800 Mechelen, Belgium

Tel +32 I5 443385

Email Philippe.vandekerckhove@ rodekruis.be
International Journal of Clinical Transfusion Medicine 2016:4 55-66

(c) (1) (8) ๑ 2016 Borra et al. This work is published and licensed by Dove Medical Press Limited. The full terms of this license are avalable at https://www.dovepress.com/terms. cc) you hereby accept the Terms. Non-commercial uses of the work are permitted without any further permission from Dove Medical Press Limited, provided the work is properly attributed. For

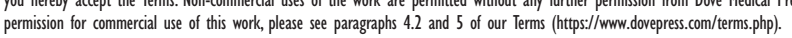

Dovepress

http://dx.doi.org// 0.2147/1]CTM.\$8452 |

\section{5}

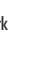


Table I Seven categories of donor deferral criteria

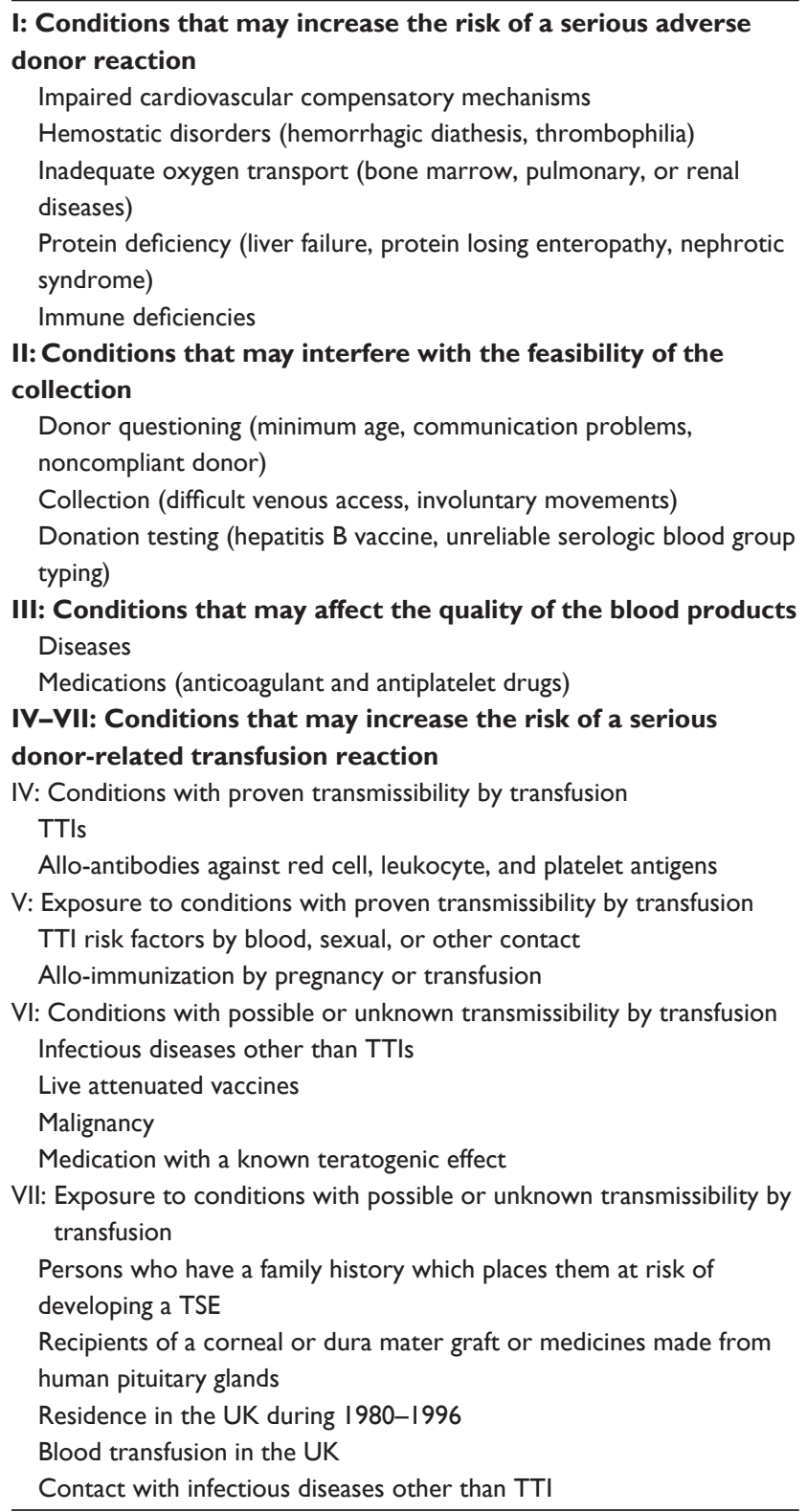

Abbreviations: TTI, transfusion-transmissible infection; TSE, transmissible spongiform encephalopathy.

Donor selection criteria were the result of a triad of historical principles: (1) the precautionary principle to ensure safety and quality, (2) supply considerations, and (3) expense considerations. This triad-based model has clear advantages: it is easy for the blood banks to work with, cheap, and very safe for the patients.

However, the model also provokes criticism. Most criticism concerns the first pillar of this model, the precautionary principle, which states that, in the interest of public health, risk management action should be taken even in the absence of certainty about risk, thus aiming for maximum safety. With regard to donor exclusion, this implies that exclusion criteria are always defined with a broad safety margin. ${ }^{3}$ For example, in Belgium, a 28-day deferral is applicable to all donors who traveled outside Europe, thereby protecting potential threats such as dengue, Chikungunya, and Zika. Thus, the field of blood transfusion seems to operate under different rules than what is most common in other fields of medicine, in the sense that the instinct and tradition of the blood-banking sector is to make blood ever safer (zero risk as the ultimate if unachievable goal).

Furthermore, there is little consideration for preferences or sensitivities on the donor side: groups of donors are readily excluded if the average infectious risk for those groups is higher than the overall average in the population, with exceptions made only if the exclusion measure threatens the overall blood supply, which is considered in the second pillar of the model. Indeed, it is only in extreme circumstances that exceptions have been considered: the UK, for instance, due to the bovine spongiform encephalopathy epidemic, decided to destroy all plasma derived from whole-blood donations within the UK, and started importing plasma from countries with a low risk of the variant Creutzfeldt-Jakob Disease. ${ }^{4}$ Taking into account the impact on supply to define the level of exclusion is a form of irrationality, as it implies that a very large group is less likely to be excluded than smaller groups. To illustrate this latter point, because of the variant CreutzfeldtJakob Disease threat, in most of continental Europe, potential blood donors who resided for $>6$ months in the UK in the period 1980-1996 are permanently excluded. If the UK used a similar approach, it would find itself without blood donors overnight. The US, on the other hand, goes a step further and even excludes donors who have spent a cumulative time of $\geq 5$ years in any combination of European countries since 1980. ${ }^{5}$ If European countries used a similar approach, they would find themselves without blood donors overnight.

In addition, and only secondary to supply considerations (and therefore groups as a whole), individual elements come into play. It is a criticism often heard for exclusion based on age, men who had sex with men (MSM), etc: not everybody in a group has the same risk or displays the same risk behavior. However relevant the differences between subgroups may be, practical and economic arguments come into play: how difficult and costly would it be to reliably differentiate individual donors within a particular population?

This brings us to the third pillar of the model: expense considerations. People not only expect to receive adequate quantities of safe blood but also expect to receive it at an acceptable price. This implies that donor selection criteria should be cheap and easy to apply during blood drives. Age exclusion criteria, for instance, could be more relevantly 
based on biological rather than chronological age, but this would drive the cost up dramatically.

In summary, it is the combination of the precautionary principle and the potential impact on the blood supply and on cost which has defined donor exclusion criteria up till now, and even when considering donor preference, economic and practical considerations were taken into account. Altogether, this resulted in comprehensive donor selection guidelines based on national legislation to which almost invariably requirements of other sources were added (such as National Haemovigilance Networks, professional advisory bodies or initiatives based on local regional epidemiological risks, and perceptions of best practice or simply custom and practice).

Alternatives to the precautionary principle exist but always make the decision-making process more complex, and hence require more and more robust scientific data. We therefore decided to apply the relatively new and powerful tool of evidence-based medicine and searched for the available evidence in the scientific literature underpinning the most common exclusion criteria. In addition, we also identified the available health technology assessments (HTAs) on safety measures in blood banking.

The aim of this paper is to provide an overview of (1) the available evidence base for donor exclusion criteria applied to the most common reasons of deferral in our region, and (2) the corresponding health economic data with regard to donor exclusion criteria, and health economic data with regard to blood-banking safety measures in general.

\section{Methods}

\section{Systematic literature search for systematic reviews, primary studies and HTAs on blood donor selection criteria} We searched MEDLINE (using the PubMed interface) for available relevant systematic reviews concerning blood donor selection criteria with the search strategy available in Supplementary materials. Next, we searched for primary research studies using the search strategy in Supplementary materials. In addition, we searched for HTAs in MEDLINE (using the PubMed interface) and the Centre for Reviews and Dissemination database, using the search strategies in Supplementary materials.

All available systematic reviews concerning blood donor selection criteria were included.

The following in- and exclusion criteria for the selection of primary research articles were used. For the outcome "infection", we included blood donors (or people eligible to give blood) living in areas most relevant for our Blood Service: Northern, Western, and Southern Europe (Albania,
Andorra, Austria, Belgium, Bosnia and Herzegovina, Croatia, Denmark, Estonia, Finland, France, Germany, Gibraltar, Greece, Iceland, Italy, Ireland, Kosovo, Latvia, Liechtenstein, Lithuania, Luxembourg, Macedonia, Malta, Monaco, Montenegro, the Netherlands, Norway, Portugal, San Marino, Serbia, Slovenia, Spain, Sweden, Switzerland, Vatican City), the USA, Canada, Australia, and New Zealand. For the outcome "donor adverse events", no geographic limitations were used. The population containing blood donors, but not exclusively blood donors, was excluded.

Risk factors included were risk factors for possible transfusion-transmissible infections or adverse events for the donor.

Outcomes included were related to possible (exposure to) infections or adverse events.

Intervention studies (randomized controlled trials, controlled clinical trials, before-and-after studies) and observational studies (case-control studies with cases either having a diagnosed infection or showing adverse events and a control group without infections of adverse events) were included. Studies had to give an indication of significance (by mentioning a $P$-value, a confidence interval, or in a narrative way). Noncontrolled studies, case reports, case series, letters, comments, opinion pieces, narrative reviews, modeling studies, or studies that fail to mention levels of significance were excluded.

The following in- and exclusion criteria for HTAs were used. Blood donors (who were deferred) from developed and/or developing countries were included. Risk factors for possible TTIs or adverse events for the donor were included. Both costs and effects (life-years gained or diseasespecific outcomes as reported in cost-effectiveness studies, quality-adjusted life-years [QALY] as reported in cost-utility studies) or a health gain expressed in monetary units (as reported in cost-benefit analyses) were included as outcomes. Cost-effectiveness analyses, cost-utility analyses, and/or costbenefit analyses were included. Studies that only reported information on costs or health effects were excluded.

Only studies in English were included.

\section{Systematic literature search for HTA on all blood banking safety measures}

In order to determine the cost/QALY for current blood bank safety measures, we searched the literature for existing HTA, using the search strategies in Supplementary materials. The following inclusion and exclusion criteria for costutility analyses were used. Blood donors from developed countries were included. Studies performed in Belgium/the Netherlands were preferably included; if not present, other settings (developed countries) were selected. Blood donors 
from developing countries were excluded. Medical health questionnaire, screening lab tests (ie, nucleic acid test for hepatitis $\mathrm{C}$ virus $[\mathrm{HCV}] /$ hepatitis $\mathrm{B}$ virus [HBV]/HIV, tests for bacteria), screening tests regarding component preparation (Intercept Blood System for platelets, pathogen inactivation), and screening tests regarding utilization (hemovigilance) were included. Screening tests for other viruses (eg, West Nile virus) were excluded. We included studies with no intervention or another screening test as a comparator. Cost/QALY was the outcome. Cost-utility analyses were included. Only studies in English were included.

\section{Analysis of the most frequent reasons for donor exclusion}

Donor deferrals are accurately recorded in the blood bank information system of the Belgian Red Cross-Flanders by using unique deferral codes. To monitor changes in donor selection, a trend analysis is performed on a regular basis by ranking deferral codes according to their frequency.

\section{Results}

\section{Evidence that supports donor selection criteria}

Table 2 gives an overview of the number of systematic reviews, primary research studies, or HTAs containing evidence that (does not) supports blood donor selection criteria.

\section{Systematic reviews}

Our search for relevant systematic reviews concerning blood donor selection criteria identified (1) two published and two unpublished reviews concerning deferral criteria aimed at donor safety, and (2) two published and one unpublished review concerning selection criteria aimed at recipient safety (Table 2).

Concerning the safety of the blood donor, one systematic review investigated the effect of pre-donation hypotension on whole-blood donor adverse reactions. The available evidence showed that hypotensive blood donors do not have a greater risk for adverse donor reactions, compared with normotensive blood donors. The overall quality of the ten included observational studies was limited and rated "low" according to the Grading of Recommendation, Assessment, Development, and Evaluation methodology. ${ }^{6}$

Another systematic review was published on the safety of blood donation from individuals with treated hypertension or non-insulin-dependent type 2 diabetes. No study indicated that increased baseline blood pressure level, and treated hypertension or diabetes, was predictive of increased adverse reactions in blood donors, but the level of overall evidence was limited. ${ }^{7}$

Recently, we performed a systematic review on wholeblood donation by epilepsy patients. Based on three observational studies, no significant association could be demonstrated between (a history of) epilepsy and complaints during or after blood donation (personal communication Centre for Evidence-Based Practice, Belgian Red CrossFlanders, 2016).

At request of the UK Blood Services Forum, a study was performed to evaluate the available evidence on the safety of accepting blood donors beyond the age of 70 . Evidence was obtained from demographic and blood service data, and an additional review of key literature was performed. Evidence showed that it is safe for regular donors of whole blood and blood components to continue donating beyond the age of 70 , with no absolute upper limit, on condition that they meet the other acceptance criteria for blood donation. ${ }^{8}$

Concerning the safety of the blood recipient, a systematic review on the safety and effectiveness of blood from uncomplicated hemochromatosis patients for blood transfusion stated that there was no evidence to suggest that blood from hemochromatosis patients without complications of iron overload is unsafe for transfusion. There was also no evidence that their blood would present a greater risk to the safety of the recipient than blood from healthy donors. However, two in vitro studies suggested that iron-overloaded patients might be more susceptible to bacterial growth, but these findings should be confirmed by in vivo studies. Also, harmonization of the blood donor selection policy among countries allowing hemochromatosis patients to donate blood once iron levels are normalized is needed. ${ }^{18}$

In 2015, a systematic review was performed to investigate whether to investigate whether male blood donors, having sex with men, present a risk of TTIs in Western countries. Fifteen low-quality observational studies suggested a link between blood donors who were MSM and HIV-1 infection, but the evidence is too limited to recommend a precise deferral period. ${ }^{31}$

Recently, a systematic review was performed on the risk of TTIs in blood donors who recently had an endoscopic examination, since the invasive procedure and the reusable character of an endoscope could threaten a safe blood supply. Twenty-eight observational studies (of very low quality) were included, and several meta-analyses showed an association between endoscopic examinations and hepatitis $\mathrm{B}$ and $\mathrm{C}$ infection. To take into account the differences in prevalence 
Table 2 Number of systematic reviews, primary research studies, or HTAs containing evidence that (does not) supports blood donor selection criteria

\begin{tabular}{|c|c|c|c|c|}
\hline \multirow[t]{2}{*}{ Donor deferral categories } & \multirow{2}{*}{$\begin{array}{l}\text { Systematic } \\
\text { reviews }\end{array}$} & \multicolumn{2}{|c|}{ Primary research studies } & \multirow[t]{2}{*}{ HTA } \\
\hline & & High quality/RCT & $\begin{array}{l}\text { Low qualityl } \\
\text { observational studies }\end{array}$ & \\
\hline $\begin{array}{l}\text { I: Conditions that may increase the risk of a serious adverse donor } \\
\text { reaction }\end{array}$ & $4^{6-8, a}$ & - & $8^{9-16}$ & $\mathrm{I}^{17}$ \\
\hline II: Conditions that may interfere with the feasibility of collection & - & - & - & $\mathrm{I}^{17}$ \\
\hline III: Conditions that may affect the quality of the blood products & $1^{18}$ & - & - & $1^{17}$ \\
\hline IV: Conditions with proven transmissibility by transfusion & - & - & $11^{19-29}$ & $2^{17,30}$ \\
\hline V: Exposure to conditions with proven transmissibility by transfusion & $2^{31, a}$ & - & $34^{19-21,23-29,32-55}$ & $2^{17,56}$ \\
\hline VI: Conditions with possible or unknown transmissibility by transfusion & $1^{18}$ & - & $3^{26,36,54}$ & $1^{17}$ \\
\hline $\begin{array}{l}\text { VII: Exposure to conditions with possible or unknown transmissibility by } \\
\text { transfusion }\end{array}$ & - & - & - & $I^{17}$ \\
\hline
\end{tabular}

Notes: The primary studies are divided in a high-quality or low-quality category, based on their study design (RCTs or observational studies, respectively). ${ }^{\text {Personal }}$ communication, Centre for Evidence-Based Practice, Belgian Red Cross-Flanders, 2016.

Abbreviations: HTA, health technology assessment; RCT, randomized controlled trial.

of these infections between European and African countries, a subanalysis was performed for European countries only, which still showed a significant association between endoscopic examinations and HBV and HCV infection (personal communication Centre for Evidence-Based Practice, Belgian Red Cross-Flanders, 2016).

\section{Primary research articles}

No high-quality studies were identified. A total of 43 lowquality observational studies were found. Table 2 shows the number of studies identified for each of the seven categories of donor deferral criteria. The identified studies either looked at risk factors for adverse events in the donor, or risk factors for possible transmission of infections such as HIV or hepatitis. Of these 43 studies, 27 performed a multivariate analysis (following univariate analysis). Here, we only mention risk factors which showed a significant effect in the multivariate analysis.

For category I of the deferral criteria, considering conditions that may increase the risk of serious adverse reactions, a total of eight studies were identified. Of these, four studies found the following significant risk factors for adverse reactions in donors: low estimated blood volume, younger age, first-time donation, female sex, higher pulse rate, lower body mass index, and race..$^{10,11,13,16}$

Eleven studies were identified that looked at conditions with proven transmissibility by transfusion (category IV). Of these, five studies found evidence showing that the following risk factors were significantly associated with transmission of infections: (history of) hepatitis, sexually transmitted diseases in males, and being HBV or HCV positive in males. ${ }^{21,23,24,27,48}$
Thirty-four studies were relevant for conditions including exposure to conditions with proven transmissibility by transfusion (category V), of which 21 performed a multivariate analysis. Significant risk factors identified in multiple studies were previous blood transfusion, (history of) injectable or intranasal drug use, tattoo, living in a closed institution (prison or juvenile detention), sex with a drug user, contact with blood from another person, body piercing, acupuncture, major or minor surgery, hospitalization, sexual promiscuity, MSM, and occupational exposure. . $0,21,23,24,27,28,33,34,37,38,41-46,48,49,51,52$

Regarding conditions with possible or unknown transmissibility by transfusion (category VI), three studies were identified. However, none of these studies performed multivariate statistical analyses. Univariate analysis showed that jaundice and elevated alanine aminotransferase are significant risk factors for infections. ${ }^{26,36}$

No studies were identified for category II (conditions that may interfere with the feasibility of the donation procedure), category III (conditions that may affect the quality of blood products), and category VII (conditions including exposure to conditions with possible or unknown transmissibility by transfusion) of the deferral criteria.

\section{Health technology assessments}

Three cost-effectiveness analyses concerning blood donor exclusion criteria were identified (Table 2). In the first study, the cost-effectiveness of the entire medical questionnaire (currently used in the Netherlands, ie, the Donor Health Questionnaire) was investigated. It was found that the incremental cost-effectiveness ratio for the Donor Health Questionnaire (including costs for deferred donors) on preventing TTIs was $€ 1,449,005$ (95\% confidence interval: $€ 669,439-€ 3,145,961)$. 
Hence, it was concluded that this medical questionnaire is not a cost-effective tool to further reduce TTIs, although its role in self-selection precludes abandoning the medical questionnaire. ${ }^{17}$ In the second study, the cost-effectiveness of using a medical questionnaire (followed by polymerase chain reaction [PCR] testing) specifically for malaria was estimated via a decision analysis model. Compared to not using a medical questionnaire, the incremental cost-effectiveness ratio was $\$ 6,463$ per case of malaria averted when using the medical questionnaire followed by PCR. ${ }^{30} \mathrm{~A}$ third analysis was a costbenefit analysis with an implicit valuation of Israel's decision (in 1990s) to exclude blood donations from Ethiopian immigrants, due to the high prevalence of HIV infection in this community relative to the rest of the Israeli population. This analysis demonstrated that this exclusion policy could not be considered as justifiable on public health grounds if the annual social exclusion costs exceed $\$ 218,000$ per year or $\$ 3.63$ per Ethiopian immigrant. ${ }^{56}$

Another form of cost is the impact of temporary deferral on donor retention with the subsequent need to attract new donors. Several studies have demonstrated that even shortterm deferral may have a significant impact on the return rate. ${ }^{57-60}$ In our own donor population, $42 \%$ of temporarily deferred donors - all reasons - in 2012 did not return within a 3-year period after donation as compared to $30 \%$ of eligible donors.

\section{HTA papers on all blood-banking safety measures currently used}

Thirteen cost-utility analyses, conducted in five Western, developed countries, were retained (Table 3 ). The HCV/ HIV antibody testing, compared to no testing, was the only cost-effective (ie, cost-saving) intervention, whereas the cost/QALY for the other interventions all exceeded the costeffectiveness threshold. Indeed, the World Health Organization indicated that the cost-effectiveness threshold would be three times the gross domestic product per head. ${ }^{61}$ For the included Western countries, this threshold ranges between $€ 90,000 / \mathrm{QALY}$ and $€ 120,000 / \mathrm{QALY}^{62}$

\section{Reasons for donor exclusion}

The top 30 reasons for excluding candidate donors who present themselves for donation in Flanders (Belgium) cover 90\% of all exclusions, and are detailed in Table 4. Low hemoglobin levels constitute $>40 \%$ of all deferrals.

When comparing Table 4 with the evidence available on donor deferral criteria (Table 2), we can conclude that for $60 \%$ of the top 30 reasons for donor deferral, no evidence is available. For $40 \%$ of the top 30 deferral reasons, only low quality evidence is available.

\section{Discussion}

Blood products are lifesaving. During donor selection, different deferral criteria are used. These criteria are based on the precautionary principle to protect safety and quality, on supply considerations to ensure access, and on expense considerations. This model has served the patients well: it provided adequate quantities of safe blood at a reasonable price.

The precautionary principle is increasingly criticized, mainly for not taking into account donor preference. Alternatives to the precautionary principle, however, always make the decision-making process more complex, and sometimes also more expensive, and hence require more and more sophisticated scientific data, and may require higher reimbursement.

This review provides an overview of (1) the available evidence base for donor exclusion criteria applied to the most common reasons of deferral at our Blood Service (Table 4), and (2) the available evidence on cost-effectiveness for blood-banking safety interventions. Given the many different reasons for donor exclusion (30 different reasons explain $90 \%$ of all exclusions), many gaps exist today in the scientific evidence: only seven systematic reviews concerning blood donor selection criteria were available, only 43 papers were found containing primary research (none of high quality), and with regard to cost effectiveness, again only three papers were found. For $60 \%$ of the top 30 deferral reasons no evidence was available, and whatever evidence was available for the remaining deferral reasons was of low quality.

The scarcity of scientific data is not surprising: if one accepts the precautionary principle as has been the case for many years, precise data are not essential to take safety measures.

The ramifications of replacing or eliminating the precautionary principle in favor of a shift to an evidencebased approach are significant. The classic triad of evidence-based work consists of the best available scientific evidence, complemented by expert opinion and by the preferences of the target population (in this case both patients and donors). In the absence of unambiguous and strong evidence, as is the case here, expert opinion and target population preference play a bigger role than if stronger quality evidence were available.

The evidence-based process can be illustrated using MSM as an example. Preference of donors is clear: they perceive 
Table 3 Cost/QALY of safety measures used in the blood-banking sector

\begin{tabular}{|c|c|c|c|c|}
\hline Intervention & Comparison & Country & Cost/QALY\# & References \\
\hline $\begin{array}{l}\text { Medical questionnaire (donor } \\
\text { health questionnaire } \rightarrow \text { prevention } \\
\text { of } \mathrm{HIV/HBV/HCV)}\end{array}$ & $\begin{array}{l}\text { No medical } \\
\text { questionnaire }\end{array}$ & the Netherlands & $696,744(3|5,422-1,6| 1,68 I)$ & de Kort et $\mathrm{al}^{17}$ \\
\hline \multicolumn{5}{|l|}{ Laboratory testing } \\
\hline $\begin{array}{l}\text { Individual-donor NAT + serologic } \\
\text { tests (HBV/HCV/HIV) }\end{array}$ & Serologic tests & Sweden & $3,726,637$ & Davidson et al ${ }^{63}$ \\
\hline $\begin{array}{l}\text { Triplex NAT (HBV/HCV/HIV) + } \\
\text { serologic tests }\end{array}$ & Serologic tests & the Netherlands & $5,200,000$ & $\begin{array}{l}\text { Borkent-Raven } \\
\text { et al }{ }^{64}\end{array}$ \\
\hline $\begin{array}{l}\text { Minipool NAT }(\mathrm{HBV} / \mathrm{HCV} / \mathrm{HIV})+ \\
\text { serologic tests }\end{array}$ & Serologic tests & USA & $2,055,000(1,370,000-2,877,000)$ & Marshall et $\mathrm{a}^{65}$ \\
\hline $\begin{array}{l}\text { Individual NAT (HBV/HCV/HIV) + } \\
\text { serologic tests }\end{array}$ & Serologic tests & & $10,001,000$ & \\
\hline \multirow[t]{2}{*}{ HIV antibody } & No test & & Cost saving & Eisenstaedt et $\mathrm{a}^{166}$ \\
\hline & & & 4,932 & AuBuchon et $\mathrm{al}^{67}$ \\
\hline HIV NAT (+ antibody) & HIV antibody & & $2,693,420$ & \\
\hline HCV antibody & No screening & & Cost saving & Busch et al ${ }^{68}$ \\
\hline HCV NAT (+ antibody) & Antibody & Spain & $2,507,100$ & Pereira et $\mathrm{a}^{69}$ \\
\hline Bacterial testing & No bacterial testing & the Netherlands & $\mid 24,254(24,864-2,86 \mid, 729)$ & Janssen et $\mathrm{al}^{70}$ \\
\hline \multicolumn{5}{|l|}{ Platelet preparation } \\
\hline $\begin{array}{l}\text { Pathogen reduction technology } \\
\text { (Intercept) }+ \text { single-donor apheresis } \\
\text { platelets (without bacterial testing) }\end{array}$ & $\begin{array}{l}\text { Untreated single-donor } \\
\text { apheresis platelets }\end{array}$ & USA & Range: I,793, I0I-6,098,760 & Bell et $\mathrm{al}^{71}$ \\
\hline $\begin{array}{l}\text { Pathogen reduction technology } \\
\text { (Intercept) }+ \text { single-donor apheresis } \\
\text { platelets (with bacterial testing) }\end{array}$ & $\begin{array}{l}\text { Untreated single-donor } \\
\text { apheresis platelets }\end{array}$ & & Range: $6,520,379-31,466,250$ & Bell et $\mathrm{al}^{71}$ \\
\hline $\begin{array}{l}\text { Pathogen reduction technology } \\
\text { (Intercept) + random-donor pooled } \\
\text { platelet concentrations }\end{array}$ & $\begin{array}{l}\text { Untreated random- } \\
\text { donor pooled platelet } \\
\text { concentrations }\end{array}$ & & $626,892-2,488,002$ & Bell et $\mathrm{al}^{71}$ \\
\hline $\begin{array}{l}\text { Pathogen reduction technology } \\
\text { (Mirasol) }\end{array}$ & $\begin{array}{l}\text { Current screens and } \\
\text { interventions }\end{array}$ & & $1,748,000(822,000-4,538,810)$ & Custer et $\mathrm{al}^{12}$ \\
\hline $\begin{array}{l}\text { Pathogen reduction technology } \\
\text { (type of technology: not reported) }\end{array}$ & $\begin{array}{l}\text { No pathogen reduction } \\
\text { technology }\end{array}$ & the Netherlands & $680,443(197,211-11,194,452)$ & Janssen et al ${ }^{70}$ \\
\hline $\begin{array}{l}\text { Pathogen reduction technology } \\
\text { (Intercept) }\end{array}$ & $\begin{array}{l}\text { No pathogen reduction } \\
\text { technology }\end{array}$ & Belgium & Range: $267,648-4,739,105$ & $\begin{array}{l}\text { Moeremans et } \\
\mathrm{al}^{73}\end{array}$ \\
\hline
\end{tabular}

Notes: \#Costs are presented in $€$. Costs were converted from $\$$ USD to $€(I €=I .37 \$)$ if needed. Data is presented as mean $(95 \% \mathrm{Cl})$, unless otherwise indicated. Abbreviations: QALY, quality-adjusted life-years; $\mathrm{Cl}$, confidence interval; HBV, hepatitis B virus; HCV, hepatitis C virus; NAT, nucleic acid test.

exclusion to be discriminatory and would like to be able to donate blood..$^{74}$ Preference of the patient population is also clear: they expect to receive the safest blood possible. Experts mostly favor exclusion of MSM due to the following reasons: 1) they take into account low-quality evidence such as extrapolations from infectious disease incidence in MSM groups, often extrapolating on data from outside the field of transfusion medicine, and there is much circumstantial evidence to support an increased risk of HIV and other sexually transmitted diseases in at least a subpopulation of gays; 2) the risk of transmission of infectious diseases, not tested for or which are (as yet) unknown, is also higher in this population; ${ }^{75,76} 3$ ) laboratory tests cannot guarantee total safety (a recent study reported an error rate of $0.01 \%$ of third- and fourth-generation HIV tests) $;{ }^{77}$ and 4) the instinct and tradition of the sector experts is to make blood ever safer, with zero risk as the ultimate goal. ${ }^{78,79}$ This is partly the result of the AIDS epidemic of the early 1980s which led to the infection of thousands of people after receiving a blood transfusion or blood products before HIV antibody testing became available. Although this situation is not comparable to the current scientific and health climate, the scare (and medicolegal consequences) of that episode still resides in many minds. As long as stronger evidence as to safety in case of MSM is not available, the precautionary principle still is valid to ensure the safety of the blood supply. However, many jurisdictions have sought to reexamine their policy on deferral of MSM guided by model-based analysis and not based on evidence. ${ }^{80}$

Replacing the precautionary principle by an evidencebased approach would thus imply certain challenges. If we do not want to replace the precautionary principle 
Table 4 Top 30 reasons of donor exclusion in Belgium

\begin{tabular}{|c|c|c|c|c|}
\hline Top 30 & Reason for donor exclusion & $\begin{array}{l}\text { Category } \\
\text { of deferral }\end{array}$ & $\begin{array}{l}\% \text { of total number } \\
\text { of exclusions }\end{array}$ & $\begin{array}{l}\text { Evidence } \\
\text { available? }\end{array}$ \\
\hline I & Low hemoglobin levels & I & $41.82 \%$ & No \\
\hline 2 & $\begin{array}{l}\text { Asymptomatic visitor of an area outside Europe } \\
\text { (Recommendation of the Belgian Superior Health Council) }\end{array}$ & $\mathrm{V}$ & $6.82 \%$ & No \\
\hline 3 & New sexual partner & $\mathrm{V}$ & $6.75 \%$ & Low quality \\
\hline 4 & Asymptomatic visitor to a malaria endemic area & $\mathrm{V}$ & $4.76 \%$ & No \\
\hline 5 & Non-specified infectious diseases & VI & $4.50 \%$ & No \\
\hline 6 & Dental treatment & $\mathrm{V}$ & $4.09 \%$ & No \\
\hline 7 & Endoscopic examination using flexible instruments & $\mathrm{V}$ & $3.58 \%$ & Low quality \\
\hline 8 & Minor surgery & $\mathrm{V}$ & $3.16 \%$ & Low quality \\
\hline 9 & $\begin{array}{l}\text { Percutaneous needle contact (tattoo, body piercing, } \\
\text { acupuncture) by a non-qualified practitioner }\end{array}$ & $\mathrm{V}$ & $3.11 \%$ & Low quality \\
\hline 10 & $\begin{array}{l}\text { Specific infectious diseases (other than viral hepatitis, } \\
\text { sexually transmitted diseases) }\end{array}$ & VI & $2.66 \%$ & No \\
\hline II & Pregnancy & I & $2.16 \%$ & No \\
\hline 12 & High blood pressure & I & $1.88 \%$ & Low quality \\
\hline 13 & Serious cardiovascular disease & I & $1.62 \%$ & No \\
\hline 14 & Low blood pressure & I & $1.47 \%$ & Low quality \\
\hline 15 & $\begin{array}{l}\text { Asymptomatic visitor of an area with ongoing transmission } \\
\text { of West Nile Virus to humans }\end{array}$ & $\mathrm{V}$ & $1.22 \%$ & No \\
\hline 16 & Malignant disease & VI & $1.20 \%$ & No \\
\hline 17 & Short interdonation interval & 1 & $1.16 \%$ & No \\
\hline 18 & Endoscopic examination using rigid instruments & $\mathrm{V}$ & $1.11 \%$ & Low quality \\
\hline 19 & Medication (with possible side effect for the recipient) & VI & $0.98 \%$ & No \\
\hline 20 & Major surgery & $\mathrm{V}$ & $0.82 \%$ & Low quality \\
\hline 21 & Body weight $<50 \mathrm{~kg}$ & I & $0.72 \%$ & Low quality \\
\hline 22 & Tick bite (Lyme disease) & VII & $0.65 \%$ & No \\
\hline 23 & Serious hematological disease & I, III & $0.65 \%$ & Low quality \\
\hline 24 & Serious central nervous system disease & VI & $0.63 \%$ & No \\
\hline 25 & Hepatitis $B$ vaccine & II & $0.58 \%$ & No \\
\hline 26 & Sexual risk behavior with temporary deferral & V & $0.45 \%$ & Low quality \\
\hline 27 & Bariatric surgery & I & $0.43 \%$ & No \\
\hline 28 & Chronic inflammatory diseases & VI & $0.36 \%$ & No \\
\hline 29 & Serious musculoskeletal system diseases & VI & $0.32 \%$ & No \\
\hline 30 & Mucosal splash or needle stick injury & $\vee$ & $0.32 \%$ & Low quality \\
\hline
\end{tabular}

(based on science, be it on weak evidence) by a mere clash of preferences (in which advocacy determines the outcome in the absence of any scientific evidence), more and better primary research and evidence-based analyses are needed.

In the meantime, policy makers should make choices at the level of general principles: whether more emphasis should be placed on donor or on patient issues (safety, preferences, etc), that is, striking the right balance between the right to donate blood versus the right to receive the safest blood possible. Selective interference at a technical level is to be avoided because mandating exceptions to the precautionary principle challenges the principle without understanding all consequences.

Furthermore, policy makers should define the right balance not only between the rights of patients and donors but also between costs and benefits of donor deferral measures. Policy decisions that replace cheap safety measures (such as the medical questionnaire) by more expensive measures (such as laboratory tests) push up the price for blood products, in a sector that already accepts exceptionally high cost-effectiveness levels. Table 3 documents the unique position of blood banking in the health care landscape. Many measures taken in the field of blood banking cost much more than the normally accepted $€ 50,000 /$ QALY limit. ${ }^{81}$ Second-generation HIV tests, for example, are estimated to cost nearly $\$ 2.7$ million/QALY. And estimates for pathogen inactivation of platelets even go as high as a mind-boggling $€ 31$ million/QALY (yet it gets introduced in many health care systems without much discussion, sometimes on the basis of one highly mediatized infection in the country). Cost/QALY could 
drop should pathogen inactivation lead to the elimination of other safety measures such as diagnostic tests, less stringent donor selection criteria, or when confronted with the outbreak of (new) epidemics for which no diagnostic tests (yet) exist or diagnostic tests are too expensive, just as cost/QALY might increase even further if lower corrected count increment results in shorter transfusion intervals or higher platelet doses, if the number of patients with platelet refractoriness increases ${ }^{82}$ or if in vitro-observed reduction in thrombus formation kinetics translates to increased bleeding risk in patients. ${ }^{83}$

However, despite the current high costs of blood transfusion, it remains an essentially cheap modality, compared to alternative interventions such as the use of erythropoietinstimulating agents (ESAs). A recent systematic review compared the cost/QALY of these ESAs with red blood cell transfusion, showing that red blood cell transfusion is still more cost-effective than the use of ESAs. ${ }^{84}$

Despite the high cost/QALY, patients are willing to pay substantial amounts for safe blood products for transfusion. ${ }^{85-87}$ The reasons why the willingness to pay in the bloodbanking sector is so high probably include several elements. On the one hand, blood seems to be a more emotional issue with a broader public, than most other health care and certainly non-health care issues. Whether this is due to the fact that blood has a symbolic value throughout history, representing life, not only in medicine but also in arts, is a possibility. On the other hand, deferral criteria are mainly regulated by legislation which can be influenced by elected politicians. Furthermore, the use of recovered plasma for fractionation is sometimes complicated by the fact that plasma-derived products typically fall under pharmaceutical legislation, for which an international market exists, whereas donor criteria for whole-blood donation typically are governed country by country.

Whatever the reasons, blindly implementing the generally accepted cost/QALY cut-off of the health care sector would have drastic consequences. If we accept a limit similar to what is applied and accepted in other fields of medicine $(€ 50,000 / \mathrm{QALY}),{ }^{81}$ many if not most measures that are routinely in use in most developed blood-banking systems would be eliminated. Whether anyone, either policy maker or blood bank professional, is willing to take responsibility for making this shift is doubtful. Acceptance for risk indeed seems to be lower when it comes to blood banking than in other areas of health care.

All in all, replacing the precautionary principle by a more evidence-based approach sounds evident but is not possible in the short term due to lack of scientific evidence. Fortunately, a tool to help streamline this process has recently been developed, defining a risk-based approach to blood-banking safety measures. ${ }^{79}$

\section{Conclusion}

Blood products save the lives of millions of people worldwide. The historical model based on the precautionary principle and on supply and expense considerations provided adequate supplies of safe blood at a reasonable price. This model is increasingly being challenged. However, it is clear that more and better primary research and evidence-based analyses are required to be able to replace this model by an evidence-based approach. In the meantime, policy makers should provide guidance at the level of principles, not at the level of technical measures, about the balance between patient and donor rights, and about the acceptable cost-effectiveness implications of these choices.

\section{Acknowledgment}

Belgian Red Cross-Flanders is responsible for supplying adequate quantities of safe blood products to hospitals in Flanders and Brussels.

\section{Disclosure}

The authors report no conflicts of interest in this work.

\section{References}

1. World Health Organization. Blood Donor Selection: Guidelines on Assessing Donor Suitability for Blood Donation. Geneva: World Health Organization; 2012.

2. Vandewalle G, Compernolle V, Vandekerckhove P. A comprehensible approach toward donor selection guidelines in Europe. 2014.

3. De Kort W, Mayr W, Jungbauer C, et al. Blood donor selection in European Union directives: room for improvement. Blood Transfus. 2016;14(2):101-108

4. United Kingdom Blood Services. Handbook of Transfusion Medicine. 5th ed. Norfolk D, editor. Sheffield: TSO; 2013.

5. American Red Cross. In-depth discussion of variant CreutzfeldJacob disease and blood donation. 2016. Available from: http://www. redcrossblood.org/donating-blood/eligibility-requirements/eligibilitycriteria-alphabetical-listing. Accessed on January 27, 2016.

6. Pauwels NS, Cusack L, De BE, Compernolle V, Vandekerckhove P. The effect of pre-donation hypotension on whole blood donor adverse reactions: a systematic review. J Am Soc Hypertens. 2014;8(6): 429-436.

7. Stainsby D, Brunskill S, Chapman CE, Doree C, Stanworth S. Safety of blood donation from individuals with treated hypertension or non-insulin dependent type 2 diabetes - a systematic review. Vox Sang. 2010;98 (3 Pt 2):431-440.

8. Stainsby D, Butler M. Recommendations for the Removal of the Upper Age Limit for Regular Whole Blood and Component Donors. Joint United Kingdom (UK) Blood Transfusion and Tissue Transplantation Services Professional Advisory Committee; 2008.

9. Callahan R, Edelman EB, Smith MS, Smith JJ. Study of the incidence and characteristics of blood donor "reactors". Transfusion. 1963;3:76-82. 
10. Gillet P, Rapaille A, Benoit A, et al. First-time whole blood donation: a critical step for donor safety and retention on first three donations. Transfus Clin Biol. 2015;22(5-6):312-317.

11. Goldman M, Osmond L, Yi QL, Cameron-Choi K, O’Brien SF. Frequency and risk factors for donor reactions in an anonymous blood donor survey. Transfusion. 2013;53(9):1979-1984.

12. Kasprisin DO, Glynn SH, Taylor F, Miller KA. Moderate and severe reactions in blood donors. Transfusion. 1992;32(1):23-26.

13. Takanashi M, Odajima T, Aota S, et al. Risk factor analysis of vasovagal reaction from blood donation. Transfus Apheresis Sci. 2012;47(3):319-325.

14. Tomasulo PA, Anderson AJ, Paluso MB. A study of criteria for blood donor deferral. Transfusion. 1980;20(5):511-518.

15. Trouern-Trend JJ, Cable RG, Baidon SJ, Newman BH, Popovsky MA. A case-controlled multicenter study of vasovagal reactions in blood donors: influence of sex, age, donation status, weight, blood pressure, and pulse. Transfusion. 1999;39(3):316-320.

16. Wiltbank TB, Giordano GF, Kamel H, Tomasulo P, Custer B. Faint and prefaint reactions in whole-blood donors: an analysis of predonation measurements and their predictive value. Transfusion. 2008;48(9):1799-1808.

17. de Kort W, van den Burg P, Geerligs H, Pasker-de JP, Marijt-van der Kreek T. Cost-effectiveness of questionnaires in preventing transfusiontransmitted infections. Transfusion. 2014;54(3 Pt 2):879-888.

18. De Buck E, Pauwels NS, Dieltjens T, Compernolle V, Vandekerckhove P. Is blood of uncomplicated hemochromatosis patients safe and effective for blood transfusion? A systematic review. J Hepatol. 2012;57(5):1126-1134.

19. Cardoso MD, Koerner K, Dengler T, Kubanek B. Identification of infection routes for HCV in blood donors from Germany. Infusionsther Transfusionsmed. 1998;25(6):370-372.

20. Conry-Cantilena C, VanRaden M, Gibble J, et al. Routes of infection, viremia, and liver disease in blood donors found to have hepatitis $\mathrm{C}$ virus infection. N Engl J Med. 1996;334(26):1691-1696.

21. Esteban JI, Lopez-Talavera JC, Genesca J, et al. High rate of infectivity and liver disease in blood donors with antibodies to hepatitis $\mathrm{C}$ virus. Ann Intern Med. 1991;115(6):443-449.

22. Murphy EL, Bryzman S, Glynn S, et al. Risk factors for hepatitis C virus (HCV) infection in US blood donors-lack of association with drug inhalation. Transfusion. 1998;38(10):73S.

23. Neal KR, Jones DA, Killey D, James V. Risk factors for hepatitis C virus infection. A case-control study of blood donors in the Trent Region (UK). Epidemiol Infect. 1994;112(3):595-601.

24. Neto CA, Sabino EC, Chen S, McFarland W, Murphy EL. Analysis of HIV seropositive blood donors risk factors-a way to improve blood donors screening. Transfusion. 2005;45(3):98A.

25. Orton SL, Stramer SL, Dodd RY, Alter MJ. Risk factors for HCV infection among blood donors confirmed to be positive for the presence of HCV RNA and not reactive for the presence of anti-HCV. Transfusion. 2004;44(2):275-281.

26. Serfaty L, Giral P, Elghouzzi MH, Jullien AM, Poupon R. Risk factors for hepatitis $\mathrm{C}$ virus infection in hepatitis $\mathrm{C}$ virus antibody ELISApositive blood donors according to RIBA-2 status: a case-control survey. Hepatology. 1993;17(2):183-187.

27. Shev S, Hermodsson S, Lindholm A, Malm E, Widell A, Norkrans G. Risk factor exposure among hepatitis $\mathrm{C}$ virus RNA positive Swedish blood donors-the role of parenteral and sexual transmission. Scand J Infect Dis. 1995;27(2):99-104.

28. Vickery K, Tawk HM, Bisset L, Selby W, Cossart YE. Hepatitis C virus infection rates and risk factors in an Australian hospital endoscopy cohort. Aust N Z J Public Health. 2009;33(5):442-448.

29. Zou S, Fujii K, Johnson S, et al. Prevalence of selected viral infections among blood donors deferred for potential risk to blood safety. Transfusion. 2006;46(11):1997-2003.

30. Shehata N, Kohli M, Detsky A. The cost-effectiveness of screening blood donors for malaria by PCR. Transfusion. 2004;44(2): $217-228$.
31. De Buck E, Dieltjens T, Compernolle V, Vandekerckhove P. Is having sex with other men a risk factor for transfusion-transmissible infections in male blood donors in Western countries? A systematic review. PLoS One. 2015;10(4):e0122523.

32. Allain JP, Mihaljevic I, Gonzalez-Fraile MI, et al. Infectivity of blood products from donors with occult hepatitis B virus infection. Transfusion. 2013;53(7):1405-1415.

33. Allison RD. A 25-year study of the clinical and histologic outcomes of hepatitis $\mathrm{C}$ virus infection and its modes of transmission in a cohort of initially asymptomatic blood donors. J Infect Dis. 2012;206(5): 654-661.

34. Busch MP, Operskalski EA, Mosley JW, et al. Epidemiologic background and long-term course of disease in human immunodeficiency virus type 1-infected blood donors identified before routine laboratory screening. Transfusion Safety Study Group. Transfusion. 1994;34(10): 858-864.

35. Chlabicz S, Grzeszczuk A, Prokopowicz D. Medical procedures and the risk of iatrogenic hepatitis $\mathrm{C}$ infection: case-controlled study in north-eastern Poland. J Hosp Infect. 2004;58(3):204-209.

36. Christensen PB, Titlestad IL, Homburg KM, Georgsen J, Kristensen T. Hepatitis B core antibodies in Danish blood donors: a surrogate marker of risk behaviour. Vox Sang. 2001;81(4):222-227.

37. Custer B, Kessler D, Vahidnia F, et al. Risk factors for retrovirus and hepatitis virus infections in accepted blood donors. Transfusion. 2015;55(5):1098-1107.

38. Delage G, Infante-Rivard C, Chiavetta JA, Willems B, Pi D, Fast M. Risk factors for acquisition of hepatitis $\mathrm{C}$ virus infection in blood donors: results of a case-control study. Gastroenterology. 1999;116(4): 893-899.

39. Delarocque-Astagneau E, Pillonel J, De VH, Perra A, Laperche S, Desenclos JC. An incident case-control study of modes of hepatitis C virus transmission in France. Ann Epidemiol. 2007;17(10):755-762.

40. Kaldor JM, Archer GT, Buring ML, et al. Risk factors for hepatitis $\mathrm{C}$ virus infection in blood donors: a case-control study. Med J Aust. 1992;157(4):227-230.

41. Karmochkine M, Carrat F, Dos SO, Cacoub P, Raguin G. A casecontrol study of risk factors for hepatitis $\mathrm{C}$ infection in patients with unexplained routes of infection. J Viral Hepat. 2006;13(11):775-782.

42. Kolho EK, Krusius T. Risk factors for hepatitis C virus antibody positivity in blood donors in a low-risk country. Vox Sang. 1992;63(3):192-197.

43. MacLennan S, Moore MC, Hewitt PE, Nicholas S, Barbara JA. A study of anti-hepatitis $\mathrm{C}$ positive blood donors: the first year of screening. Transfus Med. 1994;4(2):125-133.

44. Mast EE, Kuramoto IK, Favorov MO, et al. Prevalence of and risk factors for antibody to hepatitis E virus seroreactivity among blood donors in Northern California. J Infect Dis. 1997;176(1):34-40.

45. Mele A, Spada E, Sagliocca L, et al. Risk of parenterally transmitted hepatitis following exposure to surgery or other invasive procedures: results from the hepatitis surveillance system in Italy. J Hepatol. 2001;35(2):284-289.

46. Mitrovic N, Delic D, Markovic-Denic L, et al. Seroprevalence and risk factors for hepatitis $\mathrm{C}$ virus infection among blood donors in Serbia: a multicentre study. Dig Liver Dis. 2015;47(7):572-576.

47. Moore MC, Godfrey GS, Hewitt PE, Barbara JA. Does anti-HBc reactivity reflect 'lifestyle' risk in north London blood donors? Vox Sang. 1997;72(2):79-84.

48. Murphy EL, Bryzman SM, Glynn SA, et al. Risk factors for hepatitis C virus infection in United States blood donors. NHLBI Retrovirus Epidemiology Donor Study (REDS). Hepatology. 2000;31(3):756-762.

49. Murphy EL, Lee TH, Chafets D, et al. Higher human T lymphotropic virus (HTLV) provirus load is associated with HTLV-I versus HTLV-II, with HTLV-II subtype A versus B, and with male sex and a history of blood transfusion. J Infect Dis. 2004;190(3):504-510.

50. Neal KR, Jones DA, Killey D, James V. Injecting drug-use, health-care work and tattoos, risk-factors for hepatitis-C infection in UnitedKingdom blood-donors. Gastroenterology. 1994;106(4):A949. 
51. O'Brien SF, Fan W, Xi G, et al. Declining hepatitis C rates in first-time blood donors: insight from surveillance and case-control risk factor studies. Transfusion. 2008;48(5):902-909.

52. Schreiber GB, Murphy EL, Horton JA, et al. Risk factors for human T-cell lymphotropic virus types I and II (HTLV-I and -II) in blood donors: the Retrovirus Epidemiology Donor Study. NHLBI Retrovirus Epidemiology Donor Study. J Acquir Immune Defic Syndr Hum Retrovirol. 1997;14(3):263-271

53. Soresi M, Mazzola A, Carroccio A, et al. Transmission of hepatitis $\mathrm{C}$ virus: a study of the main risk factors in a Sicilian population of volunteer blood donors. Hepatogastroenterology. 1998;45(19): $150-153$.

54. van der Poel C, Cuypers H, Reesink H, et al. Risk factors in hepatitis C virus-infected blood donors. Transfusion. 1991;31(8):777-779.

55. Wong P-Y, Dodd R, Kiely P, Carroll C, Whyte G. Characteristics of hepatitis C-positive blood donors in Victoria, Australia. Transfus Med. 1999;9(1):15-19.

56. Kaplan EH. Implicit valuation of a blood-exclusion decision. Med Decis Making. 1999;19(2):207-213.

57. Custer B, Chinn A, Hirschler NV, Busch MP, Murphy EL. The consequences of temporary deferral on future whole blood donation. Transfusion. 2007;47(8):1514-1523.

58. Custer B, Schlumpf KS, Wright D, Simon TL, Wilkinson S, Ness PM. Donor return after temporary deferral. Transfusion. 2011;51(6): 1188-1196.

59. Hillgrove T, Moore V, Doherty K, Ryan P. The impact of temporary deferral due to low hemoglobin: future return, time to return, and frequency of subsequent donation. Transfusion. 2011;51(3): 539-547.

60. Zou S, Musavi F, Notari EP, Rios JA, Trouern-Trend J, Fang CT. Donor deferral and resulting donor loss at the American Red Cross Blood Services, 2001 through 2006. Transfusion. 2008;48(12): 2531-2539.

61. Sachs J. Macroeconomics and Health: Investing in Health for Economic Development. Geneva: World Health Organization; 2001.

62. WHO. Cost effectiveness and strategic planning (WHO-CHOICE). 2016. Available from: http://www.who.int/choice/cost-effectiveness/ en/. Accesed on January 27, 2016.

63. Davidson T, Ekermo B, Gaines H, Lesko B, Akerlind B. The costeffectiveness of introducing nucleic acid testing to test for hepatitis $\mathrm{B}$, hepatitis $\mathrm{C}$, and human immunodeficiency virus among blood donors in Sweden. Transfusion. 2011;51(2):421-429.

64. Borkent-Raven BA, Janssen MP, van der Poel CL, Bonsel GJ, van Hout BA. Cost-effectiveness of additional blood screening tests in the Netherlands. Transfusion. 2012;52(3):478-488.

65. Marshall DA, Kleinman SH, Wong JB, et al. Cost-effectiveness of nucleic acid test screening of volunteer blood donations for hepatitis $\mathrm{B}$, hepatitis $\mathrm{C}$ and human immunodeficiency virus in the United States. Vox Sang. 2004;86(1):28-40.

66. Eisenstaedt RS, Getzen TE. Screening blood donors for human immunodeficiency virus antibody: cost-benefit analysis. Am J Public Health. 1988;78(4):450-454.

67. AuBuchon JP. Cost-effectiveness of preoperative autologous blood donation for orthopedic and cardiac surgeries. Am JMed. 1996;101(2A): $38 \mathrm{~S}-42 \mathrm{~S}$.

68. Busch MP, Korelitz JJ, Kleinman SH, Lee SR, AuBuchon JP, Schreiber GB. Declining value of alanine aminotransferase in screening of blood donors to prevent posttransfusion hepatitis $\mathrm{B}$ and $\mathrm{C}$ virus infection. The Retrovirus Epidemiology Donor Study. Transfusion. 1995;35(11):903-910.
69. Pereira A, Sanz C. A model of the health and economic impact of posttransfusion hepatitis $\mathrm{C}$ : application to cost-effectiveness analysis of further expansion of HCV screening protocols. Transfusion. 2000;40(10):1182-1191.

70. Janssen MP, van der Poel CL, Buskens E, Bonneux L, Bonsel GJ, van Hout BA. Costs and benefits of bacterial culturing and pathogen reduction in the Netherlands. Transfusion. 2006;46(6):956-965.

71. Bell CE, Botteman MF, Gao X, et al. Cost-effectiveness of transfusion of platelet components prepared with pathogen inactivation treatment in the United States. Clin Ther. 2003;25(9):2464-2486.

72. Custer B, Agapova M, Martinez RH. The cost-effectiveness of pathogen reduction technology as assessed using a multiple risk reduction model. Transfusion. 2010;50(11):2461-2473.

73. Moeremans K, Warie H, Annemans L. Assessment of the economic value of the INTERCEPT blood system in Belgium. Transfus Med. 2006;16(1):17-30.

74. Roehr B. Should men who have ever had sex with men be allowed to give blood? Yes. BMJ. 2009;338:b311.

75. Friedman MR, Wei C, Klem ML, Silvestre AJ, Markovic N, Stall R. HIV infection and sexual risk among men who have sex with men and women (MSMW): a systematic review and meta-analysis. PLoS One. 2014;9(1):e87139.

76. Mayer K, Carballo-Diéguez A. Homosexual and bisexual behavior in men in relation to STDs and HIV infection. In: Holmes K, Sparling P, Stamm W, et al, editors. Sexually Transmitted Diseases. New York: McGraw-Hill Professional; 2008:203-218.

77. Taylor D, Durigon M, Davis H, et al. Probability of a false-negative HIV antibody test result during the window period: a tool for pre- and post-test counselling. Int J STD AIDS. 2015;26(4):215-224.

78. Leiss W, Tyshenko M, Krewski D. Men having sex with men donor deferral risk assessment: an analysis using risk management principles. Transfus Med Rev. 2008;22(1):35-57.

79. Menitove JE, Leach BJ, Tomasulo P, Katz LM. How safe is safe enough, who decides and how? From a zero-risk paradigm to risk-based decision making. Transfusion. 2014;54(3 Pt 2):753-757.

80. Custer B, Sheon N, Siedle-Khan B, et al. Blood donor deferral for men who have sex with men: the Blood Donation Rules Opinion Study (Blood DROPS). Transfusion. 2015;55(12):2826-2834.

81. Neumann PJ, Cohen JT, Weinstein MC. Updating cost-effectiveness-the curious resilience of the \$50,000-per-QALY threshold. $N$ Engl J Med. 2014;371(9):796-797.

82. Butler C, Doree C, Estcourt LJ, et al. Pathogen-reduced platelets for the prevention of bleeding. Cochrane Database Syst Rev. 2013;3:CD009072.

83. Van Aelst B, Feys HB, Devloo R, Vanhoorelbeke K, Vandekerckhove P, Compernolle V. Riboflavin and amotosalen photochemical treatments of platelet concentrates reduce thrombus formation kinetics in vitro. Vox Sang. 2015;108(4):328-339.

84. Ferguson T, Xu Y, Gunasekara R, et al. The cost effectiveness of erythropoietin-stimulating agents for treating anemia in patients on dialysis: a systematic review. Am J Nephrol. 2015;41(2):89-97.

85. Lee SJ, Neumann PJ, Churchill WH, Cannon ME, Weinstein MC, Johannesson M. Patients' willingness to pay for autologous blood donation. Health Policy. 1997;40(1):1-12.

86. Lee SJ, Liljas B, Churchill WH, et al. Perceptions and preferences of autologous blood donors. Transfusion. 1998;38(8):757-763.

87. Moxey AJ, O'Connell DL, Treloar CJ, Han PY, Henry DA. Blood transfusion and autologous donation: a survey of post-surgical patients, interest group members and the public. Transfus Med. 2005;15(1): 19-32. 


\section{Publish your work in this journal}

International Journal of Clinical Transfusion Medicine is an international, peer-reviewed, open access, online journal publishing clinical-experimental, policy-making and evidence-based practices of all topics pertaining to clinical transfusion medicine. Original research, short reports, reviews, case reports and commentaries are invited. The manuscript management system is completely online and includes a very quick and fair peer-review system, which is all easy to use. Visit http://www.dovepress.com/testimonials.php to read real quotes from published authors.

Submit your manuscript here: http://www.dovepress.com/international-journal-of-clinical-transfusion-medicine-journal 